\title{
Village Fund Allocation Management Competency in Kapala Pitu District, North Toraja Regency
}

\author{
Risma Niswaty $^{1 *}$, Andi Cudai Nur ${ }^{2}$, Diaz Rency Sesa ${ }^{3}$ \\ ${ }^{1}$ Public Administration Study Program, Postgraduate, \\ Universitas Negeri Makassar \\ Email: risma.niswaty@unm.ac.id \\ ${ }^{2}$ Public Administration Study Program, Postgraduate \\ Universitas Negeri Makassar \\ Email: cudainur@gmail.com \\ ${ }^{3}$ Public Administration Study Program, Postgraduate \\ Universitas Negeri Makassar \\ Email: diazrency96@gmail.com
}

(Received: January 11-2021; revised: February 25-2021; published: March 5-2021)

\begin{abstract}
This study aims to determine and describe the Competence of Village Fund Allocation Management in Kapala Pitu District, North Toraja Regency. The method used is an interactive model, namely data collection, data condensation, data presentation, and verification of conclusions. The results show that 1) The availability of adequate information about village funds is considered to have been implemented effectively. 2). Public knowledge and insights about village funds are considered to have been implemented effectively. 3). Increasing public trust in the management of the Village Fund is considered to have run effectively. 4). The increased community participation in village fund activities is considered to have been implemented effectively. Overall, it can be understood that the Competency of Village Fund Allocation Management in Kapala Pitu District, North Toraja Regency has been running effectively. project finished. So that the responsiveness of the village community in Kapala Pitu to the implementation of village governance runs well, the allocation in the implementation of the village fund program has been able to increase public trust in the village government, the result is that village development is getting more advanced. The creation of a good relationship between the community and the government through community empowerment with the labor-intensive model of the local village community is given the opportunity to implement the village fund program both in physical and nonphysical development.
\end{abstract}

Keywords: Competency Model, Village Fund Allocation, Administrative Accountability.

\section{INTRODUCTION}

Reflecting on the development of rural communities in the past, especially in the New Order era, village development is a method and approach to development programmed by the State in a centralized manner. Where village development is carried out by the government either with its own capabilities (within the country) or with the support of developed countries and international organizations. The village as a government that is directly in contact with the community is the main focus in government development, this is because most of Indonesia is 
in rural areas. Regional governments are granted greater autonomy in financing and managing regional development based on their own budget priorities.

Village Development is one of the national programs of the central government which has produced various policy programs to support Village development. This is also clearly seen in Law Number 6 of 2014 concerning Villages which has provided a strong foundation related to the Implementation of Village Government (Desa, 2013).

Funding from any village development activity requires a lot of money. In every village in Indonesia, a certain amount of village funds is allocated every year with the aim of developing the village. The use of village fund allocations is prone to misuse of funds by parties that should be trusted by the community in developing villages to be more advanced and developing, this is where the role of the community is important. as a direct supervisor and cannot be separated from the role of the district government as a funder to always monitor the development nets in the village.

Good governance is the basis for the formulation and implementation of democratic state policies in the era of globalization. The phenomenon of democracy is marked by the strengthening of public control over governance, while the phenomenon of globalization is marked by interdependence between nations, especially in the management of economic resources and activities of the business world.

In order to improve the welfare of the people in North Toraja Regency, the principle of Good Governance has become an obligation that must be carried out in the wheels of the North Toraja Regency Government as a national direction. In Law Number 23 of 2014, it is a reflection of the implementation of regional governance based on the principles of Good Governance (Anonim, 2014). Thus, local governments can provide maximum service to the community while contributing to regional development, especially North Toraja Regency.

The rise of regional autonomy encourages the Village Government to further empower the community and optimize existing resources, both from the village itself and from outside. One of the resources from outside the village is the allocation of funds from the Regional Government in the form of Village Fund Allocation. Village Fund Allocation (ADD) means that the village has the authority to regulate and manage its household in accordance with the original or given authority, which concerns the role of the village government as an organizer of public services in the village and as a companion in the planning and implementation process of regional development that involves the community at the Village level (Liu et al., 2010; R Fajri, 2015). To exercise this authority, the village government has sources of revenue that are used to finance the activities it carries out. One of the important things to consider in supporting the development implementation process in each village is financial certainty for its financing..

Government Regulation of the Republic of Indonesia Number 22 of 2015 concerning Amendments to Government Regulation Number 60 of 2014 concerning Village Funds Sourced from the State Revenue and Expenditure Budget in the Official Guidelines for Village Fund Implementation Guidelines (Peraturan Pemerintah No. 8, 2016), in Chapter III of the Allocation of Part Two of Article 12 paragraph 2, The Village Fund for each Village is calculated in a fair manner based on (1) Basic Allocation and (2) Allocation calculated by taking into account the population, poverty rate, area size, and geographic difficulty level of each Village. 
The main principles of good governance are community participation, upholding the rule of law, growth of transparency and accountability built on the basis of free flow of information and information needs to be accessible to interested parties and adequate, care for stakeholders, oriented towards equality of effectiveness and efficiency, and the existence of strategic vision.

This needs to be done because as much as $70 \%$ of the allocation of funds is allocated for community empowerment and $30 \%$ for the administration of the village government. The Village Fund, which is used for the empowerment of village communities, is directed at repairing or building village physical facilities and infrastructure, which includes repairing public facilities on a small scale and improving the environment and settlements, honorarium for the Village Fund implementation team and strengthening village institutions and other village activities deemed important (Takey \& Carvalho, 2015; Young \& Conboy, 2013). Meanwhile, the use of Village Funds for the administration of village governance is directed at supporting the implementation of village government and the operations of the Village Consultative Body.

This is in accordance with the contents of the regulation of the Minister of Home Affairs (Mendagri) No. 113 of 2014 in Chapter 2, article 2 which states that village finances are managed based on transparent, accountable, participatory principles and carried out in an orderly manner and with budget discipline. (2) The financial management of village funds as referred to in paragraph (1), is managed within one fiscal year, starting from January 1 to December 31 .

Table 1.2 The amount of funds in Kapala Pitu Village, North Toraja Regency, South Sulawesi Province in 2018 to 2019

\begin{tabular}{ccc}
\hline No. & Fiscal Year & Village Fund Allocation Amount \\
\hline 1 & 2018 & $\operatorname{Rp~} 1.056 .499 .761$ \\
2 & 2019 & $\operatorname{Rp~} 2.175 .866 .062$ \\
\hline & Total & Rp 3.232.365.821 \\
\hline
\end{tabular}

Source: Village Community Empowerment Office of North Toraja Regency

(Gasik, 2011; Trivellas \& Drimoussis, 2013) states that accountability and transparency are the main components of good corporate governance. Transparency and accountability are very important things for financial management in every organization, both government and non-government organizations. The implementation of accountability by implementing the principles of good governance is very important in every organization which includes transparency and a sense of justice, this is so that the organization is trusted by every stakeholder, therefore every organization in the government is required to implement the accountability principle.

One of the government's efforts to achieve good governance is to implement the principle of accountability. State administrative institutions in the (Lin et al., 2015; Madter et al., 2012) say it is an obligation to give accountability and explain the performance and actions of a person / legal body / leader / organization to those who have the matter or are authorized to hold accountable. This accountability includes both the success and failure of the implementation of the agency's mission. Good accountability is accountability that can show an increase in the performance of government agencies and positive changes in the behavior of employees. 
(Ayu et al., 2019; Niswaty et al., 2019) asserts that "the concept of good governance does not only involve the government but also various actors outside the government". Economic governance concerns the decision-making process that can affect the economic activities of a country and the economic relations of another country, political governance is related to the decision-making process in formulating policies, administrative governance is related to policy implementation systems

Budget order and discipline, namely village financial management must refer to the rules or guidelines that underlie it. Basically, village financial management should be guided by the following principles:

a) Financial management is planned openly through deliberations on village development planning, the results of which are outlined in the Village Regulation concerning APBDes, and implemented and evaluated openly and involving all elements of the village community;

b) All activities must be accounted for administratively, technically and legally;

c) Transparent information about village finances can be obtained by the community;

d) Financial management is carried out with the principles of being economical, directed and controlled.

(Hanifah \& Sugeng, 2015) Village Fund Allocation or DD is a special Village Allocation allocated by the Central Government through the Regional Government (District). The main objective is to accelerate the development of the Village level both physical development (facilities and infrastructure) and human resources (HR).

\section{METHOD}

According This type of research used in this research is qualitative research. The selection of qualitative research types in this research is very suitable to be used in researching the Competence of Village Fund Allocation Management in Kapala Pitu, Toraja Utara Regency because qualitative research seeks to understand the meaning of an event based on facts that occur when conducting research which is then analyzed. and the results of the analysis are used as evidence that needs to be interpreted to be used to support the truth carried out in the research.

This research uses qualitative research methods with a phenomenological approach. The use of this method is based on the reason that the focus of this research is the Competence of Village Fund Management. While the phenomenological approach aims to describe the meaning of life experiences experienced by some individuals, regarding certain concepts or phenomena, by exploring the structure of human consciousness, so here the researcher wants to know the meaning of experiences or observations experienced by the community in several villages in Kapala Pitu District regarding management transparency. 


\section{RESULT AND DISCUSSION}

Based on the data analysis carried out, the following results are presented which include: 1) the availability of adequate information regarding the allocation of village funds; 2) public knowledge of village fund allocations; 3) increased public confidence in the management of village fund allocations; 4) increased community participation in village fund allocation activities. The results and discussion for each research focus can be explained below.

\section{Availability Of Adequate Information About The Allocation Of Village Funds}

Sufficient information is one of the important aspects in improving village development, for this reason the village government plays an active role in ensuring information disclosure related to village funds to the community. The information provided to the community is actual and accurate information, not fictitious information in order to invalidate the responsibility of the village government. With sufficient information, the people of Kapala Pitu District are able to supervise any village development activities that have been jointly planned as outlined in the Village Medium Term Development Plan (RPJMDesa) and the Village Development Work Plan (RKP Desa).

Information disclosure is the responsibility of the Kapala Pitus District government as the responsibility for village government management, especially the use of village funds. The obligation to carry out information disclosure is regulated by Law no. 14/2008 concerning Openness of Public Information (UU KIP) and ministerial regulation number 6 of 2018 concerning Public Information Services and Public Complaints within the Ministry of Villages, Development of Disadvantaged Areas, and Transmigration.

The results of the tracing carried out by the author related to the availability of adequate information in Kapala Pitu District that the Kapala Pitu District government has made efforts to provide information needed by the community regarding the transparency of the use of Village Funds, including the installation of information boards in the form of banners for the use of Village Funds in general. In addition, the Kapala Pitu District government has also installed information boards for the use of the Village Fund for every physical activity and community development.

\section{Community Knowledge About Village Fund Allocations}

Community knowledge about village funds is one of the benchmarks for the success of the village government in applying the principle of transparency. Basically, all village government activities related to village funds can be known by all village communities. In this case, the community's knowledge of village funds is where the community is always aware of various physical and non-physical development programs of the Village Government and how much village funds they receive. The village community gets a variety of information that can increase community knowledge and is expected to be able to participate in various programs that will be implemented by the Government.

The level of knowledge of the people of Kapala Pitu District, which is considered by the community there, is sufficient to know from all the village fund allocations allocated for the development of Kapala Pitu village. The form of providing understanding carried out by the 
Kapala Pitu District government is in the form of delivering information through meetings with hamlet heads and local community leaders and is also carried out in the form of conveying information through an announcement board at the village office regarding the design of village activity programs along with the budget allocated for activities.

\section{Increased Public Confidence In The Management Of Village Fund Allocations}

The creation of a good government, especially in the village government, needs to pay attention to the level of community trust in order to run the organization effectively. Village government basically has a closer relationship with the community seeing the structure of village government in direct contact with the community. This is what makes the difference between the central government and the village government.

The increased public trust in the village government in managing the Village Fund is able to provide opportunities for the government in running the government. The efforts of the Kapala Pitu District government in increasing the trust of the village community have been able to be carried out well, because with the government's efforts to empower the people of Kapala Pitu District, it increases community trust. which can be seen from community participation in village programs both physical and non-physical

The Kapala Pitu District Government has good capabilities in increasing community trust in the village government and this is a progression in running the wheels of government in Kapala Pitu District. It is also able to increase effectiveness and efficiency in carrying out every village program that has been planned. With the government's efforts that focus on information disclosure including transparency in the use of village funds, the government provides opportunities for the community to have a better understanding of governance, of course, so that the community can give trust.

\section{Increased Community Participation In Village Fund Allocation Activities}

Participation is indispensable in running a good government. One of the things that increases the existing development in the village is community participation, especially the village community. Communities who have an awareness of the importance of village development will always strive to realize the wishes of the village government in developing their villages. For this reason, the government basically must have quick steps in seeking to increase public participation.

The Kapala Pitu District Government has made efforts to realize the principle of transparency regarding community participation. With the increase in community participation, it will be in line with the implementation of increased village development and the achievement of good village governance governance. The community in Kapala Pitu District has participated well in all development carried out by the village government, this can be seen from the participation of the community by being involved in deliberation activities that discuss the design of village development activities programs and involvement at the development implementation stage. 
Community participation in village government development activities can also be indicated that the Kapala Pitu District government is quite successful in nurturing and involving the community and this is a form of participatory action by the Kapala Pitu District government in carrying out its governmental duties

\section{CONCLUSION}

Overall, seeing the competence in managing the allocation of village funds in Kapala Pitu District, North Toraja Regency has been running quite well. 1) Availability of adequate information on every process of formulating and implementing public policies. The Kapala Pitu District Government is quite good because it is implemented openly, providing information on the use of village fund allocations both in nominal terms and the design of allocating funds in each activity program to be implemented, conveyed to all village communities and community leaders through village forums. Information availability is also carried out with information boards in the form of billboards and making inscriptions every time the project is completed. 2) Community knowledge about Village Fund Allocation shows quite good results. This is due to the existence of various forms of responsiveness of the community and village and sub-district government, community knowledge of village funds, seen by the understanding of the community who already knows what programs will be implemented and how they are allocated. 3) The increased public trust in the village government shows quite good results. This is evidenced by the empowerment of local village communities in village development through labor-intensive programs as long as the community has the ability to implement it. 4) The increased community participation in village fund activities seen from the dimensions of community participation in the development of the village of Kapala Pitu shows quite good results where the government's efforts are superior in applying the principle of community participation both in village development in the implementation stage with a labor-intensive model so that a symbiosis of mutually beneficial relations between the government occurs. village with village community.

\section{REFERENCES}

Aboh, J. A. (2014). Conflict management: A panacea to development. Sophia: An African Journal of Philosophy, 14(2), 64-67.

Aboh, J. A. (2015). Assassinating political opposition: An" Albatross" and aberration-the Cross River example. Sophia: An African Journal of Philosophy, 16(1), 211-215.

Aboh, J. A. (2015). Child labour and forced marriage: Modern slavery in Nigeria. Sophia: An African Journal of Philosophy, 15(2), 15-19.

Aboh, J. A., \& Effiong, E. N. (2019). A Historical Periscope of Self Inflicted Socio-Political Predicaments of Nigerians.

Agbii, S. U., Chukwu, C. E., \& Iwundu, N. (2019). Enhancing Human Capital Development through Higher Education. GNOSI: An Interdisciplinary Journal of Human Theory and Praxis, 2(1), 48-55.

Akpan, N. (2021). The Factors Militating Against the Globalization of Technology Market in Nigeria: Case Study of Abuja. GNOSI: An Interdisciplinary Journal of Human Theory and Praxis, 4(2), 18-30. 
Banker, R. D., Lee, S. Y. \& Potter, G. (1996). A field study of the impact of a performancebased incentive plan. The journal of accounting and economics, vol. 21, no. 2, pp. 195226.

Bessong, P. K., Bassey, B. E., \& Nwafor, B. C. (2019). Impact of Social Cost Accounting on Corporate Performance of Petroleum Marketing Firms in Nigeria. GNOSI: An Interdisciplinary Journal of Human Theory and Praxis, 2(1), 1-9.

Dinardo, J., \& Lee, D. S. (2011). Program Evaluation and Research Designs. In Handbook of Labor Economics (Vol. 4, Issue PART A). https://doi.org/10.1016/S01697218(11)00411-4

Dixit, A. (2002). 'Incentives and Organisations in the Public Sector'.Journal of Human Resources XXXVII.

Duncan, O. D. (1959). Human Ecology and Population Studies. In The Study of Population (pp. 678-716).

Essien, E. (2003). The Performing Artist and Marketing Problems in Nigeria. Theatre Studies Review, 3(1), 44-55.

Essien, E. (2005). The Theatre Administrator and Conflict Resolution in the Theatre. Nduñode, $6(2), 21-28$

Esu, B., \& J. Inyang, B. (2009). A Case for Performance Management in the Public Sector in Nigeria. International Journal of Business and Management, 4(4). https://doi.org/10.5539/ijbm.v4n4p98

Feyisetan, O., \& Simperl, E. (2019). Beyond Monetary Incentives. ACM Transactions on Social Computing, 2(2), 1-31. https://doi.org/10.1145/3321700

Fillman, D. S. (2010). Diabetes education and public health services. In The Diabetes educator (Vol. 36, Issue 3, pp. 363-364). https://doi.org/10.1177/0145721710370947

Fowler, S. B., \& Lapp, V. (2019). Sample size in quantitative research. American Nurse Today Research, 14(5), 61-61.

Irek, N. E. (2018). Prophetic Reflection on Good Governance in Nigeria: Discourse on Chinua Achebe's The Trouble with Nigeria Chinua Achebe and the Convolution of Immortality.

Irek, N. E., \& Charles, E. (2015). Theatre Practice in Nigeria: Surveying the Past and Present. Ifok Journal of Interdisciplinary Studies, 2(1).

Javid, B. S., \& Chapa, A. (2014). When Money is not a Motivating Force in the Work Place. Global Journal of Human-Social Science: A Arts \& Humanities - Psychology, 14(3), 0-6.

Locke, H. S. \& Braver, T. S. (2008). "Motivational Influences on Cognitive Control: Behavior, Brain Activation, and Individual Differences. Cogn. Affect. Behav.Neurosci." 8(99), 2008.

Merchant, K. A. \& Van de Steede, W. A. (2008).Management Control Systems. Essex, UK: Pearson Education Limited.

Odey, J. S., Ajor, J. O., \& Aboh, J. O. (2019). The Place of History in Mitigating National Challenges: The Case of Nigeria. International Journal of Recent Innovations in Academic Research, 3(3), 23-31.

Palmer, W. (2012). "Incentive and Disincentive: Will They Affect Performance.", 
Read, D. (2005). Monetary incentives, what are they good for? Journal of Economic Methodology, 12(2), 265-276. https://doi.org/10.1080/13501780500086180

Rivaton, R. (2018). “The era of weak competition.” In Concurrences (Vol. 2018, Issue 2, pp. 49).

Sittenthaler, H. M., \& Mohnen, A. (2020). Cash, non-cash, or mix? Gender matters! The impact of monetary, non-monetary, and mixed incentives on performance. Journal of Business Economics, 90(8), 1253-1284. https://doi.org/10.1007/s11573-020-00992-0

Sudarman, F., \& Laha, M. S. (2020). The Public's Perception of the Government Employees' Services at Fandoi District, Biak Numfor Regency, Papua Province. GNOSI: An Interdisciplinary Journal of Human Theory and Praxis, 3(3), 97-111.

Tsai, S. N. (2018). Innovative behaviour of knowledge workers and social exchange attributes of financial incentive: implications for knowledge management. Journal of Knowledge Management, 22(8), 1712-1735. https://doi.org/10.1108/JKM-07-2017-0293 
24 Jurnal Ilmiah Ilmu Administrasi Publik: Jurnal Pemikiran dan Penelitian Administrasi Publik

Volume 11 Number 1, January - Juny 2021. Page 15-24 